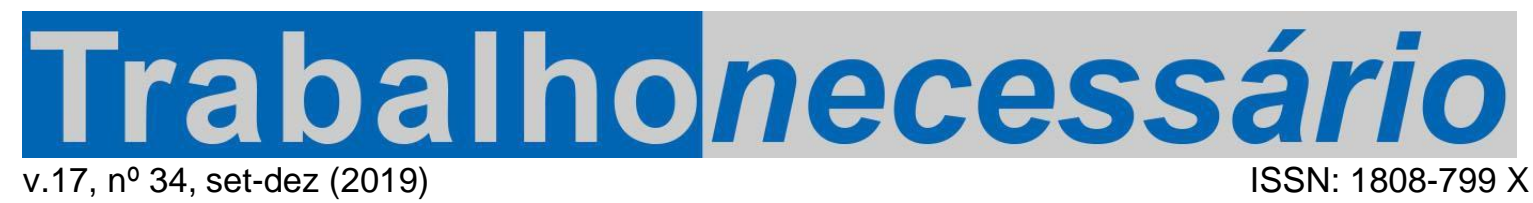

\title{
RACISMO E LUTA ANTIRRACISTA NO BRASIL: UMA ANÁLISE NECESSÁRIA PARA O AVANÇO DA ESTRATÉGIA ANTICAPITALISTA ${ }^{1}$
}

\begin{abstract}
Jacqueline Botelho ${ }^{2}$
\section{Resumo}

Este artigo pretende demonstrar a contribuição do antirracismo para a luta anticapitalista no Brasil, um país de passado escravista recente, último a abolir a escravidão, e que imprime historicamente, com o apoio do Estado, relações sociais de subordinação do negro, justificadas por uma ideologia racista que associa sua cultura e existência à condição de atraso. A luta antirracista não assume uma posição secundária em relação à luta de classes, mas à qualifica e informa, sendo o açoite do negro pela exploração do trabalho e o racismo autorizado, elementos que impõem novos limites à consciência de classe e ao movimento negro organizado.
\end{abstract}

Palavras-chave: raça, classe, racismo, movimento negro, formação social brasileira

\section{RACISMO Y LUCHA ANTIRRACISTA EN BRASIL: UN ANÁLISIS NECESARIO PARA AVANZAR EN LA ESTRATEGIA ANTICAPITALISTA}

\section{Resumen}

Este artículo pretende demostrar la contribución del antirracismo a la lucha anticapitalista en Brasil, un país con un pasado esclavista reciente, el último en abolir la esclavitud, y que históricamente imprime, con el apoyo del Estado, relaciones sociales de subordinación de los negros, justificadas por una ideología. racista que asocia su cultura y existencia a la condición de atraso. La lucha antirracista no toma una posición secundaria en relación con la lucha de clases, sino que califica e informa, el azote de los negros para la explotación del trabajo y el racismo autorizado, elementos que imponen nuevos límites a la conciencia de clase y al movimiento negro organizado.

Palabras-clave: raza, clase, racismo, movimiento negro, formación social brasileña.

\section{RACISM AND ANTI-RACIST STRUGGLE IN BRAZIL: ANANALYSIS NEEDED TO ADVANCE THE ANTICAPITALIST STRATEGY}

\begin{abstract}
This article aims to demonstrate the contribution of anti-racism to the anti-capitalist struggle in Brazil, a country with a recent slavery past, the last to abolish slavery, and which historically prints, with the support of the State, social relations of subordination of black people, justified by an ideology racist that associates its culture and existence to the condition of backwardness. The anti-racist struggle does not take a secondary position in relation to the class struggle, but rather qualifies and informs, the whipping of the black for the exploitation of work and authorized racism, elements that impose new limits on class consciousness and the organized black movement.
\end{abstract}

Keywords: race, class, racism, black movement, Brazilian social formation

${ }^{1}$ Artigo recebido em 01/08/19. Primeira avaliação em 16/08/19. Segunda Avaliação em 06/08/19. Aprovado em 30/08/19. Publicado em 27/09/2019. DOI: https://doi.org/10.22409/tn.17i34.p38049.

2 Professora Adjunta da Escola de Serviço Social da UFF. Doutora em Serviço Social (PPGSS/UERJ). Mestre em Políticas Públicas e Formação Humana (PPFH/UERJ). Assistente Social, graduada pela UERJ. Coordenação do NEPEQ/ESS-UFF. E-mail: jbotelho@id.uff.br ORCID: https://orcid.org/00000003-1989-5089 


\section{Introdução}

No resgate de uma historiografia crítica do negro brasileiro, pretende-se destacar seu protagonismo na luta abolicionista radical no passado escravista, na construção dos movimentos grevistas no Rio de Janeiro, no século XIX, na organização da luta quilombola, contribuindo fortemente para experiências de consolidação da classe trabalhadora, e em processos de resistência no campo da luta pela terra, trabalho e escola, durante a escravização negra, e mesmo após a proibição do tráfico de escravos internacional.

Os negros representaram o contingente populacional massivo segregado na sociedade capitalista no pós-abolição, cujo desafio torna-se, para além de demonstrar objetivamente esta segregação - como política de classe operacionalizada pelo Estado desde então -, denunciar permanentemente o mito da democracia racial, uma estratégia de apagamento dessa articulação racista, como forma de dominação burguesa, especialmente no Brasil, um país de capitalismo dependente, cujo processo de urbanização, independência e modernização é operado pela mediação do atraso e de relações sociais de produção que remontam o passado escravista e se alimentam do latifúndio, do analfabetismo, da instrução precária destinada aos trabalhadores, ampliando o número de negros descartados pelo mercado.

Para além de identificarmos que o discurso da falta de empregabilidade está revestido da velha inadequação racista para o trabalho, é desafio ao movimento negro interpretar que a busca da empregabilidade alimenta relações sociais que nutrem o racismo na sociedade, nas mais diversas dimensões da vida social, e não apenas no trabalho. Ou seja, a empregabilidade é uma estratégia capitalista para que a crise seja diagnosticada como de responsabilidade do trabalhador, em maioria negros e negras, que passam a ser o motivo da sua própria condição. Nesta direção, para saída da crise estrutural, busca-se o perfil empregável, adequado, supostamente aliado do progresso. Este perfil é branco, o que tornou o embranquecimento um ideal perseguido por grande parte da população negra, que buscará afastar-se de qualquer marca da escravização. Quando falamos da população negra, sua existência é a própria marca da submissão, sua cor de pele, especialmente, e todos os demais fenótipos negros recuperam a associação histórica entre trabalho braçal, manual subordinado e o próprio escravo. 
No pós-abolição, a experiência vivida do negro está fundamentada na alienação de si mesmo como elemento que não somente advém de sua experiência com o trabalho, mas que, inclusive, lhe fornece barreiras para a aproximação com a experiência assalariada, para a qual a sua inadequação justificaria a importação e, até certo ponto, financiamento da mão de obra imigrante pelo Estado brasileiro.

\begin{abstract}
A opinião de Peixoto, bastante interessante, foi emitida durante um debate público provocado pela possível chegada de negros vindos dos Estados Unidos para o estado de Mato Grosso. O presidente daquele estado, em 1921 , fez concessões de terras a colonos e pioneiros. No entanto, quando a empresa ventilou a possibilidade de que entre os colonos esperados estivesse um grupo de negros norte-americanos, o presidente de Mato Grosso rapidamente revogou as concessões que tinha feito, e imediatamente comunicou o fato ao ministro das relações exteriores. Foi quando Afrânio Peixoto, em face da perigosa ameaça daquele potencial influxo de quinze milhões de negros vindos do norte, interrogou desesperado: 'Teremos albumina bastante para refinar toda essa escória? Deus nos acuda, se é brasileiro!' (NASCIMENTO, 2017, p.88).
\end{abstract}

Curiosamente, numa sociedade que caminha na atual conjuntura para 0 rechaço à democracia, a elite passa a despir-se da negação do racismo, e passa a se sustentar não apenas pela afirmação de uma sociedade multirracial, miscigenada e de convivência harmônica entre a casa grande e a senzala. $\mathrm{Na}$ atual conjuntura, de recrudescimento do racismo, o que se afirma é a ideologia da inferioridade do negro e o direito do branco, como metáfora de poder (Fannon, 2008), em manifestar o pensamento racista e difundi-lo amplamente em sociedade, na tentativa de despolitizar o lugar social do negro na sociedade capitalista, conferindo-lhe uma conotação biologizante e estereotipada, organizada institucionalmente e no cotidiano, anunciando a atualidade do eugenismo como estratégia de setores dominantes no Brasil, que aglutina forças "díspares", capazes de reunir ultra liberais e setores conservadores para o "bem da nação" (uma ficção criada por uma elite reacionária, que, através de pactos pelo alto, autoriza mudanças sociais sem a participação real da população e sua diversidade na definição das políticas implementadas pelo Estado).

É absurda a tentativa de atenuação das evidências da condição desigual entre negros e brancos na transição para o trabalho assalariado, abrindo possibilidades para interpretações de aproximação entre a casa grande e a senzala, que permitiriam a continuidade do trabalho pelo negro como suposta oportunidade conferida pelo branco, a partir da impossibilidade de disputa do negro no mercado de trabalho pela pouca qualificação. Nessas análises são subtraídas as determinações do racismo 
estrutural - que afastou o negro do acesso à terra, ao trabalho e à escola - e se fortalece o mito do "bom senhor".

Também nos causa danos - em substituição ao movimento de explanação da situação precária do negro na sociedade escravista - imputar, pelo viés culturalista (desassociado da análise do modo de produção escravista e capitalista), uma condição de extrema resistência ao estudo do escravismo e suas contribuições para a compreensão da questão étnico-racial no Brasil, em nome da difusão desenfreada das experiências de cultura negra, que não devem apenas disputar o espaço de entretenimento na sociedade capitalista, mas possibilitar à classe trabalhadora condições de resgate da ancestralidade africana, capazes de conferir ao negro a consciência da sua realidade social e econômica, como produto da estratégia de dominação capitalista no cenário mundial.

\section{Escravização e resistência negra}

No ano de 1700, o quantitativo de escravos somava aproximadamente 330.000, chegando a quase três milhões no ano de 1800. O mercado de carne humana para o trabalho, no tráfico negreiro, contribuiu de forma decisiva para o crescimento do poder absoluto do homem sobre o homem no mundo liberal. A escravidão não permaneceu ao largo do sucesso das três revoluções liberais, visto que, ao contrário, ela conheceu o ápice de seu desenvolvimento em virtude desse sucesso. Nos anos 50 do século XIX, a população escrava nas Américas alcançava o pico de mais de 6 milhões de escravos (LOSURDO, 2006).

Na metade do século XVIII, a Grã-Bretanha possuía o maior número de escravos (878.000). A Espanha, embora com império mais extenso, a seguia a muita distância. Portugal ocupava o segundo lugar, com 700.000 escravos, atuando como uma espécie de semi-colônia da Grã-Bretanha, em que boa parte do ouro extraído pelos escravos brasileiros acabava em Londres (Ibid.).

Em ordem cronológica, os diferentes momentos da acumulação primitiva repartem-se pela Espanha, Portugal, Holanda, França e Inglaterra. Em fins do século XVII, na Inglaterra, estes momentos são resumidos sistematicamente no sistema colonial, no sistema da dívida pública, no moderno sistema tributário e no sistema protecionista. Estes métodos estiveram baseados sobre a mais brutal violência 
concentrada e organizada da sociedade. No entanto, não há dúvidas de que quem ocupa destaque nesse campo, a partir da sua "posição absolutamente eminente é o país que está no mesmo tempo na frente do movimento liberal, e que conquistou o seu primado no comércio e na posse dos escravos negros exatamente a partir da Revolução Gloriosa" (LOSURDO, 2006, p.48).

No Brasil, o cativeiro da terra foi a matriz estrutural e histórica de nossa sociedade, que condenou a modernidade e entrada no mundo capitalista no Brasil a uma modalidade de coerção do trabalho, que nos assegurou um modelo de economia concentracionista e extremamente desigual. Antes da abolição da escravidão, a Lei de Terras de 1850 já instituía um novo modelo de propriedade, em que a condição de proprietário não dependia somente da condição de homem livre, mas de pecúlio para a compra da terra, ainda que ao próprio Estado. Desta forma, de modo diferente do Brasil Colônia, a terra não seria mais concessão da Coroa Portuguesa ao sesmeiro, que recebera a terra para cultivo, e também não seria de domínio do Estado. ${ }^{3}$

O domínio sobre a terra seria uma concessão junto ao título de propriedade, que garantia ao proprietário o direito de fazer das terras um uso indiscriminado, o que trouxe graves limitações à regulação pública do seu uso. Estes elementos históricos formam evidências comprovadoras de que o desenvolvimento capitalista brasileiro não seguiu o modelo clássico, e fora definido por determinações de origem que não devem ser ignoradas pelos pesquisadores que pretendem entender as contradições do capitalismo no campo brasileiro.

Reconhecemos que a escravidão moderna no Brasil esteve diretamente ligada às relações comerciais, o que imprimiu diferenças entre a escravização negra e indígena, sendo o escravo negro a marca do escravo mercadoria, em substituição ao escravo indígena. O desenvolvimento da extração do ouro no final do Seiscentismo deixava nítida tal relação, quando se estabeleceu que a mineração do ouro e das pedras preciosas seria realizada não mais por índios cativos, mas mediante o emprego de escravos africanos, atendendo às exigências de inserção no mercado lucrativo de carne negra, e a particularidade do domínio de técnicas de trabalho mais avançadas, apresentadas por esse contingente arrancado da África.

\footnotetext{
${ }^{3}$ Ver em MARTINS, José de Souza. 0 cativeiro da terra. São Paulo: Editora Contexto, 2010
} 
As opressões justificadas ideologicamente por critérios raciais surgem com o capitalismo, diretamente associadas à legitimação ideológica da escravidão moderna, sobretudo a partir do momento em que o capitalismo começa a atingir a etapa industrial, e os movimentos abolicionistas, em escala internacional, começam a pôr em xeque a continuidade das instituições escravistas (MATTOS, 2019, p.63).

A escravização negra demonstra a perversidade da lógica de acumulação instituinte do capitalismo no Brasil, visto que além de tornar o homem mercadoria cria ideologicamente a lógica do merecimento do castigo do trabalho a quem o realiza, ajudando a tornar ainda mais degradada a imagem social do trabalho braçal e do negro em nossa sociedade, pois quem trabalha é majoritariamente o escravo, e o escravo é o negro.

Entre o final do século XVIII e princípio do século XIX, mudanças importantes ocorreram na Europa. Na tentativa de derrotar uma ordem baseada em privilégios corporativos tradicionais, os iconoclastas do Antigo Regime recorreram à filosofia dos direitos naturais. Num investimento contra o que definiam como instituições corruptas e considerando sua sociedade como fonte de todos os males, eles idealizaram os povos e as sociedades primitivas. Uma nova filosofia e nova crítica social lançaram as sementes do abolicionismo, que abalariam as antigas afirmações de que os negros seriam selvagens e primitivos, pondo em xeque a escravidão, agora pensada como uma "aberração no mundo do liberalismo" (MARTINS, 2010).

O escravo, no período Colonial, funcionava como dinheiro em sentido estrito, como meio de troca ou meio de circulação $^{4} \mathrm{e}$, na condição em que o escravo representa o investimento de uma determinada soma de recursos, pode realizar a função do capital-dinheiro emprestado a juros. $O$ aluguel de escravo foi prática comum no Brasil, onde vivia um bom contingente de indivíduos a partir da aplicação do seu dinheiro na compra de escravos (destinados a render sob locação ou como negros de ganho) (Ibid.).

Para o escravo, a liberdade não era o resultado imediato do seu trabalho, mas a negação do trabalho, visto que na sociedade escravista só é representado realmente como livre quem não precisa trabalhar para viver. Na medida em que o trabalho escravo se baseava na vontade do senhor, o trabalho livre baseava-se na vontade do trabalhador, na "aceitação" da legitimidade da exploração do trabalho pelo capital. Por

\footnotetext{
${ }^{4}$ Segundo Marx, no entendimento do processo de circulação do dinheiro e na possibilidade de sua relativa autonomia, temos o capital usurário (pré-capitalista) e o capital bancário, que é capitalista na acepção típica. (GORENDER, 2010).
} 
estes motivos, a questão abolicionista foi conduzida para garantia da substituição do trabalhador escravo pelo trabalhador livre, em que, no caso das fazendas paulistas, se traduzia na substituição física do negro pelo imigrante.

Convencidos de que a escravidão estava destinada a desaparecer, da mesma maneira que os americanos da época estavam convencidos da inevitabilidade da democracia, uma convicção que nunca fora compartilhada pelos brasileiros, os latifundiários do Brasil decidiram preparar-se para o inevitável. Já na década de 1850, os fazendeiros das áreas cafeeiras, dentre os mais necessitados de mão- de-obra, mostraram-se interessados em promover a imigração e em substituir os escravos por imigrantes. Com o fracasso das primeiras experiências, os fazendeiros de café recorreram ao tráfico de escravos interno. Posteriormente, com o aumento das pressões abolicionistas e da promulgação de leis contra o tráfico entre as províncias, os fazendeiros das áreas pioneiras buscaram na Itália os trabalhadores de que necessitavam (COSTA, 2010).

Os fazendeiros reagiram de forma diferente nas distintas áreas, mas em 1880 grande parte deles já estava convencida de que a escravidão representava uma causa perdida. Com isto, novos investimentos tinham se aberto a eles, tais como estradas de ferro, bancos e indústrias. Com a expansão do sistema de créditos, que ampliava a possibilidade de financiamento de trabalhador livre, criavam-se oportunidades de diversificar o investimento de capital, o que tornava irracional o sistema escravagista que gerava uma imobilização do capital (Ibid.)

Diferentes recursos foram utilizados pelos negreiros para prosseguirem no comércio ilícito. Bandeiras de outras nações eram hasteadas a fim de confundir os perseguidores britânicos. Os estabelecimentos ingleses da Cata Branca, Morro Velho e Congo Seco, na região das Minas Gerais, mantinham escravos. Contra os ingleses havia ainda a acusação de que africanos eram retirados dos navios negreiros e levados para Serra Leoa, onde viviam sob uma escravidão extremamente perversa. Em São João Del-Rei (MG), a Companhia Inglesa de Mineração mantinha no ano de 1856, cerca de oitocentos negros escravizados, e alugava mais de mil, situação que se estende até 1879, quando a Saint João Del Rey Gold Mining Co. foi condenada a alforriar 385 escravos. Esses fatos, que eram explorados pela opinião pública, denunciavam a incoerência da filantropia liberal britânica (COSTA, 1998, p.80). 
As relações de produção que emergiam pós-abolição estavam baseadas no trabalho livre e dependeriam de outros instrumentos coercitivos capazes de difundir uma legitimidade na exploração da força de trabalho, quando "tornava-se fundamental a figura de um trabalhador que considerasse o trabalho como uma virtude da liberdade". Estava claro que este trabalhador não emergiria de uma sociedade cujas relações essenciais de produção foram relações de extrema coerção entre senhor e escravo. "Foi estrategicamente necessário encontrar este trabalhador em outras terras que tivessem dado outro sentido à condição de homem livre." (COSTA, 1998, p.80).

Esta formação não-clássica do capitalismo no Brasil agia sobre as consciências dos trabalhadores, informando para o imigrante que a sociedade que o recebera apresentava-se como a "boa sociedade", visto que aqueles que os expulsaram da terra, servindo-lhes como algozes, não estavam em terras brasileiras para serem enfrentados.

A sociedade brasileira pretendia tornar-se capitalista sem garantir as condições mínimas de reprodução do trabalhador. Doze anos após a Lei de Terras brasileira (1850), o capitalismo norte-americano, através do governo de Abraham Lincoln, opta pela livre ocupação de suas terras para esvaziar o escravismo americano e permitir que os ex-escravos pudessem se tornar proprietários de terras para o avanço do capitalismo, o oposto da opção brasileira (MARTINS, 2010).

Nos termos de um eminente representante dos fazendeiros no Brasil, os imigrantes deveriam ser morigerados, sóbrios e laboriosos, devendo possuir as principais virtudes consagradas na ética capitalista. Desta forma, a pequena propriedade seria conquistada após o trabalho árduo, sofrimentos e privações dos primeiros tempos. Tais ideias estiveram na base da política de seleção de imigrantes no Brasil. Famílias preferiram imigrantes solteiros, sendo os italianos preferidos em relação aos trabalhadores de outras nações, visto que, a exemplo, os trabalhadores alemães predominantemente preferiam de imediato o trabalho autônomo (Ibid.).

Predominaram os italianos nas correntes migratórias vindas para o Brasil. $O$ italiano proveniente de áreas em que a economia ainda estava baseada em relações pré-capitalistas, preenchia uma condição essencial à reprodução social numa economia como a cafeeira, que mantinha características escravocratas apesar da abolição legal da escravidão. É uma crença de muitos pesquisadores a identificação da principal corrente de imigrantes italianos com regiões industrializadas da Itália, 
visto que o principal contingente de operários nas origens da industrialização brasileira era italiano (MARTINS, 2010).

Esses autores fazem tal inferência a partir da insuficiente constatação de que tais imigrantes procediam do Norte. Logo, concluía-se que, como o Norte era a região italiana mais industrializada, os imigrantes que vieram para o Brasil teriam experimentado antes uma militante existência nas regiões fabris de seu país. Tal suposição, entretanto não é correta, pois os dados estatísticos demonstram que, do Norte, o Vêneto ${ }^{5}$ era a região de onde procedia a maioria, portanto, não vinham do Norte industrializado (MARTINS, 2010).

Não se concebe a riqueza, o capital acumulado, como produto do trabalho de outros, como produto do trabalho do operário, desprovido dos meios de produção, do confronto e do antagonismo entre o capital e o trabalho, identificados no antagonismo entre capitalistas e operários. De forma contrária, o capital é percebido como o produto do trabalho do próprio capitalista, concepção que está na raiz do mais importante mito da ideologia do trabalho no Brasil. A biografia popular de Conde Matarazzo, contava ser ele um milionário de grande sucesso, proveniente da Itália no século XIX e que morreu em 1937. As pessoas acreditam, ainda que, sem provas para tal, que ele chegara no Brasil sem recursos, e que teria enriquecido pelo seu próprio trabalho que fora muito pesado e sofrido (MARTINS, 2010, p.204)

\begin{abstract}
Quando, após a Abolição, o imigrante foi introduzido no Sudeste e Sul do Brasil, essa explicação justificou porque não se aproveitava o negro como trabalhador assalariado. Com isso, ele era colocado como um ser de pura natureza, ser rítmico, dionisíaco, sexual, em comunhão apenas com as forças elementares do mundo, enquanto o branco era o racionalismo, o progresso, a civilização. Daí a tendência cultural do negro para ser jogador de futebol, sambista, malandro e a multada símbolo do sexo extraconjugal. Tudo isso aconteceu não pelo fato dele ter sido marginalizado, por terem obstruído todos os outros espaços sociais nos quais ele podia circular, mas por uma continuidade cultural, por uma tendência particular de o negro ser apenas emoção. 'A emoção é negra como a razão é helena," dizia L.S.Senghor, um dos fundadores do movimento de negritude (MOURA, 1988, p.12).
\end{abstract}

Tais elementos faziam fortalecer a crença de que os escravizados e sua condição como cativos eram produtos da sua própria estrutura psíquica, ocultando as determinações concretas da dinâmica social. No entanto, como demonstra Fernandes (2017), existem para o negro barreiras sociais associadas a barreiras raciais na luta por 'um lugar ao sol' e da 'condição de gente'.

${ }^{5} \mathrm{O}$ Vêneto era tão pobre e subdesenvolvido como o Sul. 
Tal leitura punha a qualidade e a diferença entre os trabalhadores no lugar da desigualdade das relações de produção, trazendo a concepção de que as pessoas que trabalham estão naturalmente unidas entre si, o que fortalece a concepção de que o trabalho é potencialidade, possibilidade humana e virtude dos homens de boa índole, independente das relações sociais de produção. Esta concepção traz sérias distorções na atualidade à compreensão do trabalho na realidade brasileira, à identificação dos trabalhadores como sujeitos explorados e à própria identificação do trabalhador com outros trabalhadores que identificam-se muitas vezes com 0 empresário, com o patrão, devido à forte presença do paternalismo patronal, do populismo, dos princípios da paz social e do corporativismo que balizaram as relações de classe no Brasil (MARTINS, 2010).

A libertação do trabalho seria concebida como resultado do esforço no trabalho penoso, fortalecendo a concepção de que só o trabalho redime, provocando, em torno da atividade produtiva o ideário da ascensão social e a honra do trabalho como sua condição. Para além da lógica do trabalho pelo trabalho, que traria para as relações de produção uma conotação patronal, na visão do trabalhador o trabalho é meio de libertação e de superação da dependência. Isto é, o homem se tornaria livre quando trabalhasse para si.

A história nos diz que mais de 12,5 milhões de seres humanos foram sequestrados de suas terras, e traficados como mercadoria para as Américas, quase 6 milhões deles por navios de bandeira portuguesa ou brasileira (MATTOS, 2019). Foram quase quatro séculos de trabalho compulsório negro, como parte do processo de acumulação primitiva experimentado por países como Inglaterra, França, Espanha e Portugal, garantindo a partir da criação da unidade escravo-mercadoria, relações sociais permanentes de estratificação, com forte hierarquia, subordinação e pouca mobilidade social entre senhores e escravos. A escravização no Brasil para o negro representou, portanto, algo sem precedentes do que foi experimentado no continente africano, agora transformado em mercadoria (MOURA, 1988).

O negro escravizado possuía uma média de vida muito baixa, devido as condições precárias na relação com o trabalho. Sobre a mortalidade de escravos, podemos dizer, a partir da média de idade de falecimento obtida por meio dos registros de óbitos, que a expectativa de vida de um escravo, segundo pesquisas de historiadores, gira em torno de 19 a 25 anos, sendo gritante a mortalidade infantil. 
Tal processo de abreviamento da vida do negro, demonstra que o proprietário de escravos promoveu as condições objetivas para a aceleração da absorção da condição de escravo entre os escravos, que viviam a proibição do acesso à instrução, à qualquer organização coletiva, e à manifestação religiosa. Estes processos objetivos de violência deram lugar na história oficial ao discurso da acomodação do negro à sua condição de cativo, e, com Gilberto Freyre, difunde-se a caracterização do negro como dócil, dotado de uma força bruta, cuja convivência com a Casa Grande Ihe emprestara uma certa civilidade, e, aos brancos, o exercício de uma certa benevolência.

No pós-abolição, setores conservadores se ocuparam na produção de uma historiografia racista do negro brasileiro, fundamentada no eugenismo, e produtora de um apagamento da história da resistência negra à escravização. O racismo estrutural é capaz de organizar formas expressivas de exclusão do negro do acesso ao trabalho e a escola. Em nossa formação sócio histórica, o negro foi tratado como besta selvagem, e, na sociedade capitalista, se aproxima da figura racialista do "matuto", que nada é capaz de produzir e criar sobre a terra, restando-lhe a condição de retirante. Nesta sociedade miscigenada, o racismo é atual e se manifesta explicitamente pela discriminação, mas está organizado e permanece vivo pela perpetuação material da desigualdade, que aparece naturalizando a condição de subordinação da população negra.

Nesta direção, uma pauta antirracista é essencialmente aquela que está ancorada na defesa da educação pública, que garanta o acesso de todos e todas, sem discriminação de raça, etnia, religião, contra uma política de criminalização da pobreza e da população moradora de favelas e do campo, pela defesa dos territórios das comunidades quilombolas, sem-terra, indígena, pela saúde da população negra e especialmente da mulher negra, entre outras demandas. Estes elementos confrontam a principal estratégia de dominação burguesa na atualidade, ancorada no ataque frontal à democracia.

No período escravista, a resistência negra, quando não fora perseguida diretamente, fora constrangida e controlada dentro dos marcos, em regra, eurocentrados no catolicismo, como no caso das Irmandades, que somavam ao todo cerca de 110, entre os anos de 1830 e 1890. Apesar da condição majoritária, narrada pela exigência de adesão ao catolicismo e da condição de indivíduo livre, havia experiências de irmandades no Rio de Janeiro que reuniam escravizados a partir da 
experiência em ofícios, partilhada com outros indivíduos livres, agregando trabalhadores africanos, escravizados e livres, que também utilizaram-se da greve como recurso de resistência à exploração, à exemplo do movimento dos ganhadores de Salvador, no ano de 1857 (MATTOS, 2008).

As fábricas no Rio de Janeiro, não somente representavam espaços de trabalho que nos permitiam localizar a formação da classe trabalhadora assalariada, típica do capitalismo, mas também funcionavam no século XIX, como lócus da "diversidade na exploração do trabalhador escravizado" (MATTOS, 2004). "Em relação ao emprego do trabalho escravo nas fábricas, Eulália Lobo localizou nos registros da Junta do Comércio, entre 1809 e 1849, 101 empresas. Dessas, encontrou dados sobre a mão-de-obra em 36 fábricas, das quais apenas 11 não declararam possuir escravos empregados." (MATTOS, 2004, p.236).

Concordamos com Moura $(1988,1984)$, quando reivindica a capacidade de resistência e protagonismo negro - inclusive durante a escravização, e fundamentalmente para a explosão da abolição -, e também zela contra possíveis argumentos culturalistas, psicanalistas e biotipológicos para justificar a condição de subordinação do negro. Desta forma, "o negro brasileiro, para muitos cientistas sociais das décadas de 30 e 40, era dionisíaco, daí a sua extroversão permanente, o seu comportamento expansivo e ao mesmo tempo passivo" (MOURA, 1988, p.13).

Neste sentido, o modo de produção escravista, que suscitava essas contradições, passa a ser substituído por uma leitura harmônica dessa estrutura, e, a partir disto, "os movimentos aculturativos representavam apenas uma rejeição por parte dos negros dos padrões culturais do senhor e não uma decorrência da sua situação de escravo" e da posição de homem desumanizado, "transformado em simples coisa" (Id., p. 10).

O conflito social passava a ser substituído por choques culturais, definindo a escravização negra como um mero pano de fundo estático. A partir de Nina Rodrigues, estiveram nessa posição quase todos aqueles que escreveram sobre a escravização moderna, incluindo espaços como os três Congressos afro-brasileiros ocorridos em 1935, 1937 e 1954, tomando como fio condutor a polarização de duas culturas, seus níveis de convergência e divergência, e "as posições antagônicas do seu mundo religioso, da sua culinária, dos seus gostos musicais, indumentária, linguagem etc." (MOURA, 1988, p.10-11). 
Esta reflexão de Moura (ibid.) sobre os riscos de uma leitura culturalista do período escravista, nos auxilia a pensarmos os mesmos riscos para a leitura da exploração do trabalho na sociedade capitalista.

\begin{abstract}
Quando, inclusive, estudava-se o tráfico negreiro e a sua importância numérica tinha-se mais preocupação de saber-se a procedência regional desses escravos para aferir-se o seu nível de importância cultural no conjunto da sociedade brasileira. $O$ mesmo fenômeno se repetia quando se estudava a família negra, os seus ajustes e desajustes dentro dos padrões normativos da sociedade escravista, ou, posteriormente da sociedade competitiva que a substituiu. (MOURA, 1988, p. 11).
\end{abstract}

É nosso desafio recuperarmos a relevância das manifestações da cultura negra, associadas a análise do modo de produção, sem a qual caminhamos na busca de uma "natureza negra orientadora", que pode ser resgatada superficialmente, sem mediações com a realidade social do negro na sociedade capitalista, e sem causar incômodo aos setores dominantes, uma vez que foram eles que inventaram palavras como tolerância e diferença, tomando o padrão branco como referência. Nestas condições, o movimento negro pode perder sua força, reduzindo suas pautas exclusivamente a luta contra a intolerância, na defesa da diversidade, dentro dos marcos legais de uma luta contra o racismo, sem o questionamento da sua estrutura, também organizada pelas relações de classes. Para uma luta pujante é preciso ir além, não bastando ser contra o racismo, sendo necessário imprimir uma luta antirracista, como analisa Davis (2016).

Desta forma, concordamos com Moura (1988) que a história do negro brasileiro não pode ser compreendida sem a história da escravização negra. Nas palavras do autor, esta escolha nos permite um compromisso com a verdade histórica, a partir da qual denunciamos o brutal processo de violência contra o negro e sua cultura, sequestrados do continente Africano e inseridos numa outra sociedade como "coisas", revelando a produção organizada de sua desumanização. Na mesma proporção, precisam ser difundidos na sociedade, e especialmente nas escolas públicas, o ensino sobre a resistência e luta do povo negro, na demonstração da experiência quilombola, da capoeira, como estratégia de garantia do sentido público da escola, que deve ser financiada pelo Estado, mas organizada pelo povo.

Estamos situando elementos que contribuíram inclusive para o apagamento da história de resistência negra, pois o apagamento do conflito escravista, em nome do choque cultural, fortalece um viés naturalista da cultura. Desta maneira, as organizações negras, e sua articulação ou desarticulação, eram interpretados a partir 
da existência de "tendências culturais do negro, da sua estrutura psíquica mais emotiva do que racional, e com isso justificava-se a sua marginalização". O negro era aquele sem aptidões políticas, que deveria ser representado em suas causas pelo branco (MOURA, 1988).

A relevância numérica, tempo de duração e forma como foi abolida a escravização negra no Brasil foram os determinantes para a emergência do modelo de capitalismo dependente, em que estamos mergulhados na atualidade. A possibilidade de formação de uma burguesia nacional, nos moldes clássicos, fora estrangulada. Foi permitida a penetração do capital monopolista nos ramos mais dinâmicos e relevantes de nossa economia e "reelaboraram uma ideologia reflexa das relações de produção escravistas: o racismo." (MOURA, 1988, p.16).

Desta forma, o primeiro passo para a compreensão da unidade entre luta antirracista e anticapitalista no Brasil é a compreensão da construção da raça, em sentido biológico para dominação das Américas, seguido pela apreensão da materialidade do trabalho escravo, sua historicidade e a diversidade de escravos e seus ofícios no campo e na cidade, que os definem como cruciais para o processo de urbanização do país, quando muitos escravizados exerciam o ofício de barbeiros, médicos, vendedores ambulantes, escravas prostitutas de ganho. Na mineração havia os escravos ourives, ferreiros, pedreiros, mestres de oficinas, carpinteiros, parteiras, correios, elementos fundamentais que mostram o seu protagonismo na constituição da sociedade capitalista e o seu lugar social historicamente subordinado.

Nesse sentido, passamos a reconhecer o conteúdo estrutural do racismo, que não precisa de intenção para manifestar-se em sociedade, sendo fundamental que o combate ao racismo não se faça apenas com o seu repúdio moral e denúncias (extremamente necessários), mas fundamentalmente através de ações antirracistas concretas (ALMEIDA, 2019).

\section{O protagonismo negro nas lutas sociais: contribuições do passado para desvendar o presente}

O racismo estrutural no Brasil educa, na perspectiva dominante, o próprio negro, cumprindo a função de mantê-lo em um lugar social determinado, produzindo um processo de convencimento de que sua condição é natural - não explicitando as conexões com a sociedade de classes e com o Estado-, cabendo, como caminho para 
sua superação, não apenas o que se coloca ideologicamente a todos os trabalhadores (buscar a realização de escolhas educativas corretas, qualificação para inserção no mercado de trabalho), que são responsabilizados pela sua condição de pobreza, com forte apelo moral ao bom comportamento e civilidade, mas também, para o negro, a promoção do embranquecimento na negação de si mesmo.

O negro aparece como o diferente a ser discriminado e incapaz de atingir as características necessárias ao desenvolvimento. Para ele, o embranquecimento aparece também como exigência para o ingresso e permanência no mercado de trabalho. Tudo o que nele reside como cultura é discriminado, sua religião, o jongo, a capoeira. Todos esses elementos são satanizados, sendo a cultura negra excluída dos currículos escolares. Na escola, a ausência desse conteúdo educa a sociedade, informando, pela ausência, que essas experiências não são relevantes, e que não contribuem para a vida em sociedade. O passado escravista é reduzido assim à narrativa do negro escravizado, amarrado ao tronco e açoitado, completamente subordinado, sem que haja menção às experiências quilombolas, sua organicidade, contribuição à economia e processos de resistência para negros e não-negros naquela sociedade.

A luta antirracista exige uma educação antirracista, uma historiografia do negro que aborde o seu protagonismo, apoio às lutas quilombolas e à cultura negra resistentes no jongo, na capoeira e nas religiões de matrizes africanas (que são atacadas pelo racismo religioso). É nesse terreno que se fortalecem as experiências e a consciência de classe e racial, a partir de lutas que agregam a classe trabalhadora, composta majoritariamente por negros e mestiços. No entanto, cabe um processo de resistência para além da afirmação superficial da cultura negra, já captura pelo empresariado através da lógica do "empreendedorismo negro". O negro precisa estar organizado nos locais de trabalho, nos sindicatos, nos partidos, levando para o interior destes espaços a pauta antirracista, possibilitando o diálogo com as comunidades, com a periferia das cidades e do campo, denunciando o genocídio negro promovido pelo Estado.

De acordo com dados do Instituto de Segurança Pública (ISP), são 434 casos de autos de resistência só nos primeiros quatro meses deste ano no Rio de Janeiro. São os piores números dos últimos 20 anos. O estado do Rio vive um aumento da militarização da vida legitimado pelos próprios governantes. Exemplo disso é a fala de Wilson Witzel, governador do Rio, que em 2018, antes de tomar posse, em entrevista ao jornal O Estado de São Paulo, afirmou que: "O correto é matar o bandido que está de fuzil. A polícia vai fazer o 
correto: vai mirar na cabecinha e... fogo! Para não ter erro" (MARTINS, 2019, $\mathrm{s} / \mathrm{p}$.$) .$

Concordamos com a definição de movimento negro no sentido amplo adotado por Santos (1997), para quem as rebeliões de escravos, a formação de quilombos e as irmandades representaram experiências importantes da organização e solidariedade entre negros escravizados e negros libertos. Assim, a luta pela liberdade e por melhores condições de vida nascem no Brasil com a chegada do negro escravizado (PEREIRA, 2010).

Considerando o movimento social em sentido estrito nascendo em 1931, com a Frente Negra Brasileira (FNB), conseguimos identificar que em seus dois nascimentos, o movimento negro enfrenta diretamente contextos de repressão brutal. Nos anos 30 no Brasil, sob a ditadura varguista, ele denuncia a segregação racial, a falsa abolição, ainda buscando a integração do negro na sociedade. Nesse período da história do país, vivíamos sob um Estado de orientação fascista com estímulo à imigração europeia com vistas ao desenvolvimento da nação (DOMINGUES, 2007).

Com a extinção da FNB, sob a ditadura do Estado Novo, em 1944, sob a liderança de Abdias Nascimento, é criado, no Rio de Janeiro, o Teatro Experimental do Negro, que publicava o jornal Quilombo e oferecia curso de alfabetização, corte e costura, além de fundar o Instituto Nacional do Negro, o Museu do Negro e organizar o I Congresso do Negro Brasileiro. A atuação do TEN buscava a adesão dos partidos de esquerda na denúncia da existência de discriminação racial no país, negada pelo Estado (Id.).

Considerando o acúmulo da luta do movimento negro organizado, em 1951 é aprovada a primeira lei antidiscriminatória do país, batizada como Afonso Arinos, após um escândalo de racismo no país, que envolveu a bailarina negra norte-americana Katherine Dunham, que fora impedida de se hospedar num hotel em São Paulo. "Com a instauração da ditadura militar em 1964, o TEN ficou moribundo, sendo praticamente extinto em 1968, quando seu principal dirigente, Abdias do Nascimento, partiu para o autoexílio nos Estados Unidos" (Id.).

No final dos anos 1970 acontece a reorganização política da bandeira antirracista, no contexto de recrudescimento dos movimentos populares, sindical e estudantil, quando em 1978 nasce o Movimento Negro Unificado (MNU), inspirandose na luta a favor dos direitos civis dos negros nos EUA e referenciando-se em movimentos de libertação dos países africanos, sobretudo de língua portuguesa, 
como Guiné Bissau, Moçambique e Angola. Com o objetivo de fortalecer o poder político do povo negro, o MNU toma como proposta a unificação das lutas antirracistas, assumindo como estratégia a disputa do Estado restrito. Em 1978, o Movimento Negro Unificado já elaborava a Carta de Princípios que trazia a reivindicação por uma autêntica democracia racial (PEREIRA, 2010). O movimento reconhece a necessidade de fazer a luta antirracista na sociedade brasileira, fortalecendo reivindicações por democratização, que devem estar ancoradas também em um projeto por uma outra sociedade, anticapitalista.

O movimento negro contemporâneo vive desafios: superar o reformismo, elevar a luta contra o racismo à luta antirracista pela denúncia do racismo estrutural, combater a leitura reducionista do "negro no poder" e o processo de cooptação que atinge parte dos dirigentes e militantes do movimento negro e outros movimentos sociais, engessando suas potencialidades como organizadores da luta classista. A aproximação orgânica com a luta de classes como estratégia de ação do Movimento Negro, abre possibilidades concretas para a luta antirracista no Brasil, resgatando a construção do poder popular como elo central para o sucesso dessas ações.

A luta do povo negro também é a luta pelo acesso à escola, não só na atualidade, mas desde o século XIX, quando mães de meninos pretos e pardos, no período de escravização, buscavam formas de garantir a instrução dos filhos como estratégia de resistência, acesso ao conhecimento para novas possibilidades de ofício, com a crise da escravização, e especialmente luta pela abolição. A escola de Pretextato da Silva Passos, autodeclarado preto e provavelmente liberto (como se deduz da ausência de registros históricos que narrem sua condição como cativo), funcionava na Rua da Alfândega no Rio de Janeiro como alternativa para meninos pretos e pardos estudarem "sem coação e com perfeição" (SILVA, 2000).

Tratou-se de uma escola primária particular, desvinculada do aprendizado de
ofícios específicos e urbana (na freguesia de Sacramento), destinada a
atender meninos "pretos e pardos" - cuja maioria dos pais não possuía
sobrenome e nem assinatura própria -, criada em 1853 por um certo
professor que se autodesignou "preto". Ele requereu, em 1856, ao então
inspetor geral da Instrução Primária e Secundária da Corte (Eusébio de
Queirós), algumas concessões para a continuidade do funcionamento dessa
escola (SILVA, 2002, p. 149).

$\mathrm{Na}$ atualidade, as reivindicações de acesso à educação são frutos das demandas históricas levantadas também pelo movimento negro contemporâneo. A Lei 10.639/03, que altera a Lei 9.394 de 1996, e que inclui no currículo oficial da Rede 
de Ensino a Obrigatoriedade da Temática "História e Cultura Afro Brasileira", ainda encontra limites diversos na sua implementação. Essa seria uma possibilidade de realizarmos um enfrentamento no campo das políticas sociais públicas de Educação para que a cultura da população negra possa fazer parte da formação da consciência da classe trabalhadora.

Desta forma, situamos a luta pelo direito à educação e à escola pública no Brasil a partir do protagonismo daqueles que foram primeiramente e massivamente alijados da escola em nosso país: os negros e negras. Ao explicitarem a negação do direito à

escola, explicitam a negação do conteúdo público desta escola, que desumaniza negros e negras. Soma-se à exclusão da escola, a exclusão do mercado de trabalho.

Assim, o negro, assume uma posição de vanguarda na luta contra a exploração da força de trabalho na sociedade capitalista, devido sua condição de subordinação entre os oprimidos, que o torna capaz de denunciar com maior rigidez o conjunto de desigualdades da sociedade de classe.

A função principal para aqueles que pretendem empenhar-se na luta negra antirracista e anticapitalista, é apropriar-se das reflexões de Solano Trindade na definição de que nem todos os brancos são seus inimigos, assim como nem todos os negros são seus irmãos. Assim, não pretendemos nos limites deste artigo realizar um histórico do Movimento Negro no Brasil, com experiência extremamente larga, mas sublinhar como as experiências constitutivas do Movimento Negro estiveram diretamente conectadas com a dinâmica de classes e com a organização da sociedade capitalista dependente.

\section{CONSIDERAÇÕES FINAIS}

A luta antirracista, com a potencialidade de refutar 0 argumento da escravização e pobreza como incapacidade natural da raça, tem como desafio combater a alternativa meritocrática capitalista, e, sobretudo, a ideologia do embranquecimento como sinônimo de desenvolvimento.

Sob o argumento de que o racismo se expressa de forma estrutural e institucional em nossa sociedade, o movimento negro tem como desafio difundir, fortalecer e criar estratégias de engajamento do negro nas lutas sociais, considerando 
seu protagonismo histórico como conteúdo necessário ao avanço do conjunto das lutas da classe trabalhadora.

Apesar da afirmação de muitos de que o preconceito de cor é um fenômeno de classe, e que no Brasil não existem barreiras raciais, estas barreiras são evidentes. Nesta direção, a promoção, o reconhecimento de valor e acesso a vários empregos são negados por causa da condição racial, ainda que os argumentos apresentados, mais sirvam como pretextos que escondam as razões verdadeiras (FERNANDES, 2017).

Refutando os argumentos de Silvio Romero, segundo o qual a vitória na luta pela vida pertencerá ao porvir branco, Nascimento (2017), demonstra como teorias científicas forneceram suporte para o racismo arianista, cuja finalidade era eliminar o negro. O genocídio negro mostra-se de forma atual, organizado e estruturado na sociedade, servindo-se do branqueamento e violência como estratégias de eliminação do negro, o que permite a aceitação de uma realidade desigual entre brancos e negros pertencentes a mesma classe social.

$\mathrm{Na}$ atualidade, cabe ao movimento negro o desafio de compreender a unidade classe, raça e também gênero, evidenciando a atualização do racismo na sociedade brasileira, na superação da negação do preconceito racial, pertencente ao ethos cristão nos anos 1950, substituído pelo cinismo da elite brasileira, e pela fascista reivindicação do direito às manifestações de ódio contra o "diverso".

O fato é que "muitas pessoas passaram a exigir o direito de ser branco, o direito de não gostar de negros[...] querem seus empregos roubados pelos imigrantes, querem se sentir seguros em seu país", criando um cenário de "pânico moral" que irá justificar medidas de exceção dentro e fora da legalidade (ALMEIDA, 2019, p.189).

Neste sentido, concordamos com Fernandes (2017) que, assim como no passado, cabe aos negros conquistar a sua autoemancipação coletiva, rompendo amarras contra uma situação desumana, "ultrajante e insustentável”, que prende o conjunto da sociedade ao passado e a padrões de dominação racial extremamente obsoletos.

A superação do racismo exige o combate à sua naturalização cotidiana (Almeida, 2019), contra a qual o negro precisa defender-se com organização política e acesso ao conhecimento. A luta pela permanência e ampliação do acesso da população negra à Universidade e escola pública é um dos passos concretos 
imprescindíveis, onde o protagonismo negro, através de sua trajetória de subordinação e exclusão desses espaços, se faz urgente, hasteando a bandeira da democracia sobre a qual a classe trabalhadora se reconhece. Nessa direção, cabe à classe apropriar-se do debate antirracista, analisar criticamente a condição capitalista dependente brasileira, e qualificar a luta cotidiana na transformação da história.

\section{Referências}

ALMEIDA, S. Racismo Estrutural. SP: Sueli Carneiro; Pólen, 2019.

COSTA, E.V. Da monarquia à República: momentos decisivos. 9.ed. São Paulo: UNESP, 2010.

Da senzala à colônia. São Paulo: Fundação Editora da UNESP, 1998.

DAVIS, A. Mulheres, Raça e Classe. São Paulo: Boitempo, 2016.

DOMINGUES, P. Movimento Negro Brasileiro: alguns apontamentos históricos. Tempo vol.12 no.23 Niterói 2007. Disponível em: http://www.scielo.br/scielo.php?script=sci_arttext\&pid=S1413-77042007000200007

FANNON, F. Pele negra, máscaras brancas. Bahia: Editora Edufba, 2008.

FERNANDES, F. Significado do protesto negro. São Paulo: Expressão popular, Perseu Abramo, 2017.

GORENDER, J. O escravismo colonial. São Paulo: Fundação Perseu Abramo, 2010.

LOSURDO, Domenico. Contra-história do liberalismo. São Paulo: Ideias \& Letras, 2006.

MARTINS, G. Movimento negro vai à CIDH denunciar governo do Rio e pacote "anticrime" de Moro. Brasil de Fato. São Paulo: maio de 2019. Acesso em 29/08/19. Disponível em: https://www.brasildefato.com.br/2019/05/09/movimento-negro-vai-acidh-denunciar-governo-do-rio-e-pacote-anticrime-de-sergio-moro/

MARTINS, J de S. O cativeiro da terra. São Paulo: Editora Contexto, 2010.

MATTOS, M.B. A classe trabalhadora: de Marx ao nosso tempo. São Paulo: Boitempo, 2019.

Escravizados e livres: experiências comuns na formação da classe trabalhadora carioca. Rio de Janeiro: Bom texto, 2008.

. Trabalhadores escravizados e livres na cidade do Rio de Janeiro na segunda metade do século XIX. Revista Rio de Janeiro n.12. jan-abril, 2004. 
MOURA, C. Rebelião na senzala: quilombos, insurreições, guerrilhas. São Paulo: Ciências Humanas, 1988.

. Os quilombos e a rebelião negra. São Paulo: Editora Brasiliense,1984.

NASCIMENTO, A. O Genocídio do Negro Brasileiro: processo de um racismo mascarado. SP: Perspectiva, 2017.

PEREIRA, A. "O mundo negro": a constituição do movimento negro contemporâneo no Brasil (1970-1995). 2010. 349f. Tese (Doutorado em História), Instituto de Ciências Humanas - UFF, Niterói, 2010.

SANTOS, J.R. Culturas Negras, Civilização Brasileira. Revista Patrimônio Histórico e Artístico Nacional. Negro Brasileiro. Brasília: DF, n.25, IPHAN, 1997.

SILVA, Adriana Maria P. A escola de Pretextato dos Passos e Silva: questões a respeito das práticas de escolarização no mundo escravista. Revista Brasileira de História da Educação. N.4. jul/dez/2002.

Aprender com perfeição e sem coação. Uma escola para meninos pretos

e pardos na corte. Brasília: Editora Plano, 2000. 